\title{
Is SUV Corrected for Lean Body Mass Superior to SUV of Body Weight in ${ }^{68} \mathrm{Ga}-\mathrm{PSMA} \mathrm{PET} / \mathrm{CT}$ ?
}

\author{
${ }^{68} \mathrm{Ga}$ PSMA PET/BT'de Yağsız Vücut Kütlesine Göre Düzeltilmiş SUV Vücut Ağırlığına \\ Göre Hesaplanan SUV'den Daha mı Üstün?
}

(1) Ayşegül Aksu1, Qamze Çapa Kaya²

IUniversity of Health Sciences Turkey, Başakşehir Çam and Sakura City Hospital, Clinic of Nuclear Medicine, Istanbul, Turkey

2Dokuz Eylül University Faculty of Medicine, Department of Nuclear Medicine, Izmir, Turkey

\begin{abstract}
Objectives: This study aimed to investigate the relationship between the standard uptake value (SUV) of body weight and SUV corrected for lean body mass (SUL) parameters obtained from the prostate gland in gallium-68 $\left({ }^{68} \mathrm{Ga}\right)$-prostate-specific membrane antigen (PSMA) positron emission tomography-computed tomography (PET/CT) with Gleason grade (GG) groups, D'Amico risk groups, and presence of metastases.

Methods: Patients with prostate adenocarcinoma who underwent ${ }^{68} \mathrm{Ga}-\mathrm{PSMA}$ PET/CT for staging at our center between February 2017 and

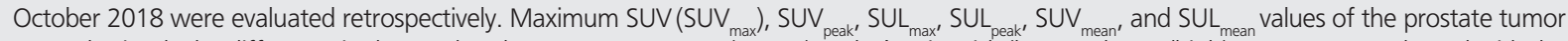
were obtained. The difference in these values between GG groups $(\geq 3,<3)$ and $D^{\prime}$ 'Amico risk (low-moderate/high) groups was evaluated with the Mann-Whitney U test. The area under the curve values of SUV and SUL parameters were compared. In addition, SUV $V_{\text {mean }}$ and SUL ${ }_{\text {mean }}$ values were obtained from the right liver lobe, and their correlation with body weight was evaluated.

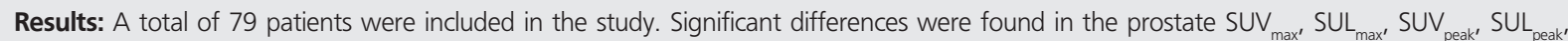
$S U V_{\text {mean' }}$, and $S U L_{\text {mean }}$ values between the GG $(\geq 3$ and $<3)$ groups and between D'Amico risk (low-moderate and high) groups. However, no significant difference was found in the discriminative power of any SUV or SUL parameter when compared with each other. A significant difference in any SUV and SUL parameters was found in patients with and without metastasis. Neither liver SUV $V_{\text {mean }}$ value nor SUL ${ }_{\text {mean }}$ value correlated with the body weight.

Conclusion: The superiority of SUL values obtained from ${ }^{68} \mathrm{Ga}-\mathrm{PSMA}$ PET to SUV was not determined in our study. SUV parameters can also be used for quantitative analysis in ${ }^{68} \mathrm{Ga}$-PSMA PET.

Keywords: SUV, SUL, lean body mass, prostate specific membrane antigen
\end{abstract}

Öz

Amaç: Amacımız, galyum-68 ( $\left.{ }^{68} \mathrm{Ga}\right)$-prostat spesifik membran antijeni (PSMA) pozitron emisyon tomografisi-bilgisayarlı tomografide (PET/BT) prostat bezinden elde edilen standart uptake değeri (SUV) ve yağsız vücut kütlesine göre düzeltilmiş SUV (SUL) parametrelerinin Gleason grade (GG) grupları, D’Amico risk grupları, metastaz varlı̆̆ı değerlendirmedeki ilişkilerinin araştııımasıdır.

Yöntem: Merkezimizde şubat 2017-Ekim 2018 tarihleri arasında prostat adenokarsinomu tanısı ile evreleme amaçı ${ }^{68 G a-P S M A ~ P E T / B T ~}$

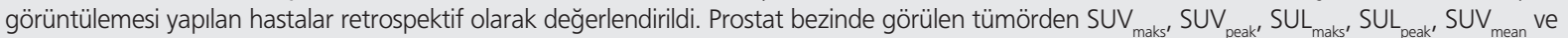
$\mathrm{SUL}_{\text {mean }}$ değerleri elde edildi. GG grupları $(\geq 3,<3$ ), D’Amico risk grupları (düşük-orta/yüksek) arasında bu değerler arasındaki fark Mann-Whitney

Address for Correspondence: Ayşegül Aksu MD, University of Health Sciences Turkey, Başakşehir Çam and Sakura City Hospital, Clinic of of Nuclear Medicine, İstanbul, Turkey

Phone: +90 5079623575 E-mail: aaysegulgedikl@gmail.com ORCID ID: orcid.org/0000-0002-6239-0660 Received: 15.02.2021 Accepted: 02.05.2021

${ }^{\circ}$ Copyright 2021 by Turkish Society of Nuclear Medicine

Molecular Imaging and Radionuclide Therapy published by Galenos Yayınevi. 
U testi ile değerlendirildi. SUV ve SUL parametrelerinin eğri altındaki alan değerleri karşıllaştııldı. Ayrıca karaciğer sağ lobundan SUV $V_{\text {mean }}$ ve SUL $_{\text {mean }}$ değerleri alınarak vücut ağırlığı ile korelasyonları değerlendirildi.

Bulgular: GG grupları ( $\geq 3$ ve $<3$ ) arasında ve D’Amico risk grupları (düşük-orta ve yüksek) arasında prostat SUV maks',$S_{L_{\text {maks' }}} S U V_{\text {peak' }} S U L_{\text {peak' }^{\prime}}$ SUV $_{\text {mean }}$ ve SUL $L_{\text {mean }}$ değerlerinde istatistiksel olarak anlamlı farkllıklar izlendi. Bununla birlikte, herhangi bir SUV veya SUL parametresinin bu grupları ayırt etme gücünde diğerine kıyasla önemli bir fark elde edilemedi. Metastaz olan ve olmayan hasta gruplarında hiçbir SUV ve SUL parametresinde istatistiksel olarak anlamlı bir fark saptanamadı. Ne karaciğer SUV mean $_{\text {değeri ne de SUL }}$ mean değeri vücut ağırlığı ile ilişkili değildi.

Sonuç: ${ }^{68} \mathrm{Ga}-P S M A$ PET'den elde edilen SUL değerlerinin SUV'ye üstünlüğü çalışmamızda belirlenememiştir. ${ }^{68} \mathrm{Ga}-\mathrm{PSMA}$ PET'de SUV parametrelerinin kantitatif analiz için de kullanılabileceği düşünülmektedir.

Anahtar kelimeler: SUV, SUL, yağsız vücut kütlesi, prostat spesifik membran antijeni

\section{Introduction}

Positron emission tomography/computed tomography (PET/CT) is becoming a standard component of the diagnosis and staging in the field of oncology. Especially, ${ }^{18}$ flourine-fluorodeoxyglucose ( $\left.{ }^{18} \mathrm{~F}-\mathrm{FDG}\right)$ PET/CT is used to quantify radiopharmaceutical uptake and quantitatively determine treatment response in the evaluation of the metabolic response in various tumors $(1,2,3)$. PET images are analyzed in clinical practice either qualitatively using visual comparison of metabolism in lesions with normal tissue or semi-quantitatively using standard uptake values (SUV). SUV is obtained as the tissue concentration (MBq/ $\mathrm{mL})$ divided by the injected activity $(\mathrm{MBq} / \mathrm{g})$ per body weight (BW). Factors affecting SUV have been discussed in many studies $(4,5,6)$. Since fat contributes to BW but accumulates very little ${ }^{18} \mathrm{~F}$-FDG in a starvation state, SUV is relatively increased in patients who are obese than in thinner ones. A study found that lean body mass (LBM) SUV (SUL) correction is a more suitable quantitative method than BW or body surface area for patients who are obese (7).

Prostate-specific membrane antigen (PSMA) is a highly expressed human transmembrane protein that is low or moderate in normal or hyperplastic prostate tissues and high in primary adenocarcinomas and distinguishes malignant lesions from benign lesions with high accuracy and positively correlates with the degree of expression, tumor aggression, metastatic disease, and recurrence $(8,9,10,11)$. In the literature, studies have shown that the SUV values obtained from a prostate tumor are higher as the Gleason score (GS) and prostate-specific antigen (PSA) value increase. Gafita et al. (12) investigated whether SUL is a more appropriate quantitative method than SUV, which is normalized by BW in gallium-68 $\left({ }^{68} \mathrm{Ga}\right)$-PSMA 11 PET/CT. They found that correction with lean BW disrupts positive correlations between absolute SUV and BW and that SUL may be preferred over SUV for quantitative analysis in ${ }^{68} \mathrm{Ga}$ PSMA 11 PET (12).

This study aimed to investigate the relationship between the SUV and SUL parameters obtained from the prostate tumor according to Gleason grade (GG) groups, D'Amico risk groups, and presence of metastasis in ${ }^{68} \mathrm{Ga}$-PSMA PET/ CT and to determine whether SUL is superior to SUV.

\section{Materials and Methods}

\section{Patients}

Patients with prostate adenocarcinoma who underwent ${ }^{68} \mathrm{Ga}-\mathrm{PSMA} \mathrm{PET} / \mathrm{CT}$ for staging at our center between February 2017 and October 2018 were evaluated retrospectively. GG groups of patients were obtained from prostatectomy material in patients undergoing prostatectomy and fine-needle biopsy results in other patients. D'Amico criteria was considered for risk stratification [low risk group (PSA $<10 \mathrm{ng} / \mathrm{mL}$ and $\mathrm{GS}<7$ and T1-T2a), intermediate-risk group (PSA $10-20 \mathrm{ng} / \mathrm{mL}$ or GS 7 or T2b-T2c), and high-risk group (PSA $>20 \mathrm{ng} / \mathrm{mL}$ or GS 8-10 or T3-T4)] (13). Patients were divided into two groups according to their $\mathrm{GG}$ ( $\geq 3$ vs $<3$ ).

\section{PET Image Analysis}

Patients signed the informed consent form, and radiation safety and imaging protocol were described. An average of 3.2 millicurie (mCi) ${ }^{68} \mathrm{Ga}-P S M A$ Imaging and Therapy was injected intravenously. Low-dose CT was used for attenuation correction an hour after injection. PET images were obtained for $1.5 \mathrm{~min}$ in each bed position in the supine position from the vertex to the toe tip in Philips Gemini TF PET/CT (Eindhoven, Netherlands). Row action maximum likelihood algorithm was used for reconstruction.

Patients who had PSMA expression on ${ }^{68} \mathrm{Ga}$-PSMA PET/CT images, which could be differentiated from background activity and thought to be related to prostate adenocarcinoma metastasis (PSMA-RADs 4 and 5) were considered to have metastatic disease (14).

Weights and heights of the patients were measured before imaging. LBM was calculated with the formula developed by Janmahasatian $(15,16)$.

$\mathrm{LBM}=\left(9.27 \times 10^{3} \times \mathrm{BW}\right) /\left(6.68 \times 10^{3}+216 \times \mathrm{BMI}\right)$ 
In the prostate gland, a region of interest was drawn on the area where PSMA expression was observed above background activity. Maximum SUV (SUV $\left.{ }_{\text {max }}\right), S_{\text {mean' }}$ and $S_{U} V_{\text {peak }}$ values were obtained from this area. $S U L_{\text {max' }}$ $S U L_{\text {mean }}$ and $S U L_{\text {peak }}$ values were calculated from $S U V_{\text {max' }}$ SUV $_{\text {mean' }}$, and SUV $V_{\text {peak }}$ values using the LBM value obtained from the Janmahasatian formula.

$S U L=S U V \times L B M / B W$

In addition, a 3-cm volume of interest (VOI) was drawn to the right liver lobe to determine liver background activity. Liver SUV $V_{\text {mean }}$ and liver $S U L_{\text {mean }}$ values were obtained from this VOI (17).

\section{Statistical Analysis}

The free version of the Statistical Package for the Social Sciences v. 26.0 was used for statistical analysis. The

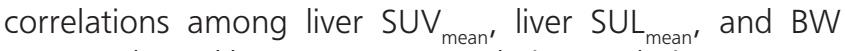
were evaluated by Spearman correlation analysis. A $p<0.05$ value was considered significant.

The difference in SUV max' $S U L_{\text {max }^{\prime}} S U V_{\text {mean }^{\prime}} S U L_{\text {mean }^{\prime}} S U V_{\text {peak' }}$ and $S U L_{\text {peak }}$ values from the prostate tumor between lowmoderate and high-risk groups was analyzed with the Mann-Whitney $U$ test. In addition, the difference in the SUV and SUL values between GG groups, between PSA groups ( $\geq 10$ and $<10 \mathrm{ng} / \mathrm{mL}$ ), and between D'Amico risk groups (low-moderate and high) was evaluated with the Mann-Whitney U test.

The potential of SUV and SUL parameters in distinguishing GG groups and risk groups was evaluated by the receiver operating characteristics analysis. The area under the curve $(A \cup C)$ values were compared, and significant difference between them was evaluated.

\section{Ethics Approval}

Dokuz Eylül University Ethics Committee approval was obtained (decision no: 2020/18-37, date: 10.08.2020). All procedures performed in studies involving human participants were in accordance with the ethical standards of the institutional research committee and with the 1964 Helsinki declaration and its later amendments or comparable ethical standards. All patients gave their informed consent before their inclusion in the study.

\section{Results}

The study included 79 patients with a mean age of $65 \pm 7$ (range, 44-78) years and mean BW of 81.5 \pm 14.5 (range, 53-125) kg. The median PSA value was 16 (range, 0.02$527.00) \mathrm{ng} / \mathrm{mL}$. A total of 13 patients had a history of radical prostatectomy.
In this study, 7 (9\%) patients had GG 1, 21 (27\%) had GG 2, 12 (15\%) had GG 3, 15 (19\%) had GG 4, and 24 (30\%) had GG 5. In ${ }^{68} \mathrm{Ga}-\mathrm{PSMA}$ PET/CT, 41 (52\%) patients did not have metastasis, while 38 patients had PSMA expression suggesting metastasis. Moreover, $33(41.8 \%)$ patients had lymph node metastasis. Five of these patients had PSMA expression in cervical/ mediastinal lymph nodes, 16 in abdominal lymph nodes, and 33 in pelvic lymph nodes. In addition, 19 (24.1\%) patients had PSMA expression suggesting bone metastasis, whereas 2 (2.5\%) patients had PSMA expression suggesting pulmonary metastasis. In the study group, no patient had liver metastasis. According to the D'Amico risk groups, two patients had low risk, 18 (22.8\%) patients had moderate risk, and 59 (74.7\%) patients had high-risk.

The mean \pm standard deviation and median (range) values from the prostate tumor were calculated as follows: SUV ${ }_{\text {max' }}$ 11.5 \pm 9.3 and 8.0 (3.0-49.8); SUL $L_{\max }$ value, 8.4 \pm 6.1 and 6.1 (2.2-34.4); SUV $V_{\text {peak }}$ value, 8.6 \pm 7.2 and 5.8 (2.4-37.6); $\mathrm{SUL}_{\text {peak }}$ value, $6.3 \pm 4.5$ and 4.5 (1.7-25.9); SUV ${ }_{\text {mean }}$ value, $5.0 \pm 2.6$ and 4.2 (1.9-13.8); and SUL $L_{\text {mean }}$ value, 3.7 \pm 3.3 and $3.2(1.3-9.4)$.

A significant difference was found in the prostate $S U V_{\text {max' }^{\prime}}$ SUL $L_{\text {max' }} S U V_{\text {peak' }} S U L_{\text {peak' }} S U V_{\text {mean' }}$ and $S U L_{\text {mean }}$ values between patients with GG $\geq 3$ and $<3$ (Table 1). However, when comparing AUC values of SUV and SUL parameters in distinguishing GG groups, no SUV/SUL parameters were superior to the other (Table 2).

No significant difference was observed in any SUV and SUL parameters between patients with GS $3+4$ and $4+3$.

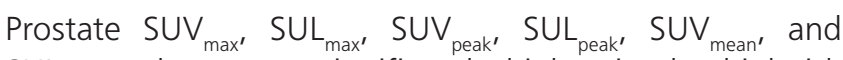
$\mathrm{SUL}_{\text {mean }}$ values were significantly higher in the high-risk group than in the other D'Amico risk groups (Table 1). However, no SUV/SUL parameter was superior to others in distinguishing risk groups (Table 2).

While all SUV and SUL parameters were higher in patients with a PSA value $\geq 10 \mathrm{ng} / \mathrm{mL}$ than in those with $<10 \mathrm{ng} /$ $\mathrm{mL}$ (Table 1), no significant difference was found in the discrimination power of any SUV and SUL parameters (Table 2).

No significant difference was found in any SUV and SUL parameters in patient groups with and without metastasis. The mean liver SUV ${ }_{\text {mean }}$ value was calculated as $4.0 \pm 1.1$ (1.8-7.6), and the liver $S U L_{\text {mean }}$ value was 3.0 1.4 (1.4-5.5). The liver SUV $V_{\text {mean }}$ and SUL $L_{\text {mean }}$ values did not correlate with BW ( $p=0.387$ and 0.132 , respectively). 


\section{Discussion}

In this study, a significant correlation was found with the BW of neither SUV $V_{\text {mean }}$ nor SUL $\mathrm{L}_{\text {mean }}$ obtained from the liver. Gafita et al. (12) reported that SUL can be preferred over SUV in ${ }^{68} \mathrm{Ga}$-PSMA 11 PET/CT. In this study, while the liver SUV $_{\text {mean }}$ value showed a significant correlation with BW, no significant correlation was found in the $S U L_{\text {mean }}$ value. Despite the few studies on this subject, similar to our study, Li et al. (2) evaluated the ${ }^{18}$ F-DCFPyL uptake but could not detect a significant correlation between liver $\mathrm{SUV}_{\text {mean }}$ and $\mathrm{SUL}_{\text {mean }}$ values and BW; as a result, they suggested using the SUV.

Several studies have also shown that PSMA SUV data are successful in differentiating GG groups and risk groups $(18,19,20,21)$. Likewise, we were able to obtain significant differences in SUV parameters between these groups. However, our study is the first to evaluate the relationship between the success of SUL and SUV parameters obtained from ${ }^{68} \mathrm{Ga}$-PSMA PET in differentiating GG groups and risk groups. In our study, SUL parameters obtained from ${ }^{68} \mathrm{Ga}$-PSMA PET were not superior to SUV parameters in distinguishing GG groups and in distinguishing risk groups. Moreover, the studies that quantified uptake with bodyweight-corrected SUV and LBM-corrected SUV have shown that the repeatability coefficient of $S U L_{\max }$ and SUV $_{\text {max }}$ within the same patient in a test-retest setting is comparable $(22,23,24)$. These results show that SUL and SUV parameters are not superior to each other in ${ }^{68} \mathrm{Ga}$ PSMA PET in clinical practice.

Prostate SUV and SUL parameters were significantly higher in patients with $G G \geq 3$ than in $G G \leq 2$, and this is similar to the findings in the literature. Onal et al. (25) reported that SUV ${ }_{\text {max }}$ values obtained from primary tumors in 191 patients were significantly higher in patients with GS $>7$.

\begin{tabular}{|c|c|c|c|c|c|c|c|}
\hline & & \multicolumn{2}{|l|}{ GG } & \multicolumn{2}{|c|}{ D'Amico risk groups } & \multicolumn{2}{|l|}{ PSA } \\
\hline & & GG $<3$ & GG $\geq 3$ & Low-moderate & High & $<10 \mathrm{ng} / \mathrm{mL}$ & $\geq 10 \mathrm{ng} / \mathrm{mL}$ \\
\hline \multirow{4}{*}{$S U V_{\max }$} & Mean \pm standard & $7.6 \pm 4.5$ & $13.7 \pm 10.5$ & $6.6 \pm 3.9$ & $13.2 \pm 10.0$ & $8.1 \pm 5.6$ & $13.8 \pm 10.5$ \\
\hline & Median (range) & $5.4(3.1-17.5)$ & $10.5(3.0-49.8)$ & $5.2(3.0-15.4)$ & $10.2(3.4-49.8)$ & $3.6(3.0-26.7)$ & $11.0(3.5-49.8)$ \\
\hline & $p$ value & \multicolumn{2}{|l|}{0.003} & \multicolumn{2}{|l|}{0.001} & \multicolumn{2}{|l|}{0.001} \\
\hline & $\operatorname{A\cup C}(95 \% \mathrm{Cl})$ & \multicolumn{2}{|c|}{$0.706(0.588-0.823)$} & \multicolumn{2}{|c|}{$0.755(0.637-0.872)$} & \multicolumn{2}{|c|}{$0.705(0.587-0.823)$} \\
\hline \multirow{4}{*}{$S U L_{\max }$} & Mean \pm standard & $5.6 \pm 3.4$ & $9.9 \pm 7.4$ & $4.9 \pm 2.9$ & $9.6 \pm 7.3$ & $5.9 \pm 4.1$ & $10 \pm 7.4$ \\
\hline & Median (range) & $4.0(2.4-12.7)$ & $7.5(2.2-34.4)$ & $3.8(2.2-11.1)$ & $7.3(2.4-34.4)$ & $4.4(2.2-19.9)$ & $8.4(2.5-34.4)$ \\
\hline & $p$ value & \multicolumn{2}{|l|}{0.002} & \multicolumn{2}{|l|}{0.001} & \multicolumn{2}{|l|}{0.001} \\
\hline & $\operatorname{AUC}(95 \% \mathrm{Cl})$ & \multicolumn{2}{|c|}{$0.709(0.592-0.826)$} & \multicolumn{2}{|c|}{$0.760(0.644-0.875)$} & \multicolumn{2}{|c|}{$0.707(0.589-0.825)$} \\
\hline \multirow{4}{*}{$S U V_{\text {mean }}$} & Mean \pm standard & $3.8 \pm 1.6$ & $5.6 \pm 2.9$ & $3.4 \pm 1.1$ & $5.5 \pm 2.8$ & $3.8 \pm 1.6$ & $5.7 \pm 2.9$ \\
\hline & Median (range) & $3.2(2.1-7.6)$ & $4.9(1.9-13.8)$ & $3.2(1.9-5.5)$ & $4.9(2.1-13.8)$ & $3.3(2.0-8.0)$ & $4.9(1.9-13.8)$ \\
\hline & $p$ value & \multicolumn{2}{|l|}{0.002} & \multicolumn{2}{|l|}{0.001} & \multicolumn{2}{|l|}{0.001} \\
\hline & $\operatorname{AUC}(95 \% \mathrm{Cl})$ & \multicolumn{2}{|c|}{$0.707(0.591-0.823)$} & \multicolumn{2}{|c|}{$0.750(0.636-0.863)$} & \multicolumn{2}{|c|}{$0.703(0.588-0.819)$} \\
\hline \multirow{4}{*}{$S U L_{\text {mean }}$} & Mean \pm standard & $2.8 \pm 1.2$ & $4.1 \pm 2.0$ & $2.5 \pm 0.9$ & $4.1 \pm 3.5$ & $2.8 \pm 2.4$ & $4.2 \pm 3.7$ \\
\hline & Median (range) & $2.4(1.3-5.8)$ & $3.5(1.4-9.4)$ & $2.4(1.9-4.4)$ & $3.5(1.3-9.4)$ & $2.4(1.5-6.0)$ & $3.0(1.3-9.4)$ \\
\hline & $p$ value & \multicolumn{2}{|l|}{0.002} & \multicolumn{2}{|l|}{0.001} & \multicolumn{2}{|l|}{0.001} \\
\hline & $\operatorname{AUC}(95 \% \mathrm{Cl})$ & \multicolumn{2}{|c|}{$0.714(0.597-0.830)$} & \multicolumn{2}{|c|}{$0.756(0.643-0.870)$} & \multicolumn{2}{|c|}{$0.703(0.587-0.819)$} \\
\hline \multirow{4}{*}{$S U V_{\text {peak }}$} & Mean \pm standard & $5.6 \pm 3.5$ & $10.2 \pm 8.1$ & $3.5 \pm 2.8$ & $9.9 \pm 7.7$ & $5.9 \pm 4.2$ & $10.3 \pm 8.2$ \\
\hline & Median (range) & $3.9(2.5-13.3)$ & $7.7(2.4-37.6)$ & $3.5(2.4-11.3)$ & $7.7(2.6-37.6)$ & $4.3(2.5-19.0)$ & $8.2(2.4-37.6)$ \\
\hline & $p$ value & 0.003 & & $<0.001$ & & 0.001 & \\
\hline & AUC (95\% Cl) & $0.701(0.582-0$ & 820) & $0.767(0.649-0.8$ & & $0.706(0.588-0$ & 324) \\
\hline & Mean \pm standard & $4.1 \pm 2.6$ & $7.4 \pm 5.5$ & $3.5 \pm 2.2$ & $7.2 \pm 5.5$ & $4.4 \pm 3.0$ & $7.5 \pm 5.8$ \\
\hline & Median (range) & $2.8(1.9-2.5)$ & $5.5(1.7-25.9)$ & $2.7(1.7-9.0)$ & $5.5(1.9-25.9)$ & $3.1(1.8-14.2)$ & $6.0(1.7-25.9)$ \\
\hline $\mathcal{S U} L_{\text {peak }}$ & $p$ value & 0.003 & & $<0.001$ & & 0.001 & \\
\hline & AUC (95\% Cl) & $0.705(0.586-0$ & 825) & $0.769(0.651-0.8$ & 87) & $0.700(0.582-0$ & 19) \\
\hline
\end{tabular}




\begin{tabular}{|c|c|c|c|}
\hline & $\begin{array}{l}\text { GG } \\
(\geq 3 \text { and }<3)\end{array}$ & $\begin{array}{l}\text { D'Amico risk } \\
\text { groups } \\
\text { (low-moderate } \\
\text { and high) }\end{array}$ & $\begin{array}{l}\text { PSA } \\
(\geq 10 \text { and }<10 \\
\mathrm{ng} / \mathrm{mL})\end{array}$ \\
\hline$S U V_{\text {max }}-S U L_{\text {max }}$ & 0.732 & 0.668 & 0.838 \\
\hline$S U V_{\text {max }}-S U V_{\text {peak }}$ & 0.721 & 0.324 & 0.935 \\
\hline$S U V_{\text {max }}-S U L_{\text {peak }}$ & 0.983 & 0.420 & 0.744 \\
\hline$S U V_{\text {max }}-S U V_{\text {mean }}$ & 0.945 & 0.808 & 0.933 \\
\hline SUV ${ }_{\text {max }}-S U L_{\text {mean }}$ & 0.750 & 0.953 & 0.943 \\
\hline$S U L_{\text {max }}-S U V_{\text {peak }}$ & 0.578 & 0.666 & 0.945 \\
\hline$S U L_{\text {max }}-S U L_{\text {peak }}$ & 0.761 & 0.560 & 0.595 \\
\hline$S U L_{\text {max }}-S U V_{\text {mean }}$ & 0.916 & 0.617 & 0.850 \\
\hline$S U L_{\text {max }}-S U L_{\text {mean }}$ & 0.830 & 0.883 & 0.848 \\
\hline SUV $_{\text {peak }}-$ SUL $_{\text {peak }}$ & 0.664 & 0.829 & 0.484 \\
\hline$S U V_{\text {peak }}-S U V_{\text {mean }}$ & 0.746 & 0.383 & 0.891 \\
\hline$S U V_{\text {peak }}-S U L_{\text {mean }}$ & 0.574 & 0.696 & 0.905 \\
\hline$S U L_{\text {peak }}-S U V_{\text {mean }}$ & 0.924 & 0.333 & 0.869 \\
\hline$S U L_{\text {peak }}-S U L_{\text {mean }}$ & 0.660 & 0.573 & 0.868 \\
\hline$S U V_{\text {mean }}-S U L_{\text {mean }}$ & 0.577 & 0.654 & 1.000 \\
\hline
\end{tabular}

In their study, Uprimny et al. (18) did not find a significant difference in SUV $V_{\max }$ values between GG 2 and 3 tumors. Similarly, Ergül et al. (19) did not found a significant difference in SUV ${ }_{\text {max }}$ values between grade 2 and 3 tumors. In addition, in our study, neither SUV ${ }_{\max }$ values nor other SUV and SUL values were detected differently in tumors with GG 2 and 3.

In a previous study, Ergül et al. (19) analyzed 78 patients and found a significant difference in SUV max $_{\text {values of }}$ prostate tumors with and without metastasis. However, Liu et al. (20) did not observe a significant difference in SUV ${ }_{\text {max }}$ in patients with and without metastasis. In the present study, similar to the study of Liu et al. (20), no significant difference was found in any SUV and SUL parameters between these groups.

\section{Study Limitations}

First, the retrospective design limits the generalizability of the results. Second, histopathological correlation is not technically and ethically possible from all foci considered metastasis. Finally, prostatectomy could not be applied to all patients, and the GS of some patients could only be obtained from the biopsy sample.

\section{Conclusion}

In this study, the superiority of SUL values obtained from ${ }^{68} \mathrm{Ga}$-PSMA PET to SUV was not determined. We think that both SUV and SUL parameters can be used for quantitative analysis in ${ }^{68} \mathrm{Ga}$-PSMA PET.

\section{Ethics}

Ethics Committee Approval: Dokuz Eylül University Ethics Committee approval was obtained (decision no: 2020/1837, date: 10.08.2020).

Informed Consent: Retrospective cross sectional study. Peer-review: Externally peer-reviewed.

\section{Authorship Contributions}

Surgical and Medical Practices: A.A., Concept: A.A., G.Ç.K., Design: A.A., G.Ç.K., Data Collection or Processing: A.A., Analysis or Interpretation: A.A., Literature Search: A.A., G.Ç.K., Writing: A.A., G.Ç.K.

Conflict of Interest: No conflict of interest was declared by the authors.

Financial Disclosure: The authors declared that this study has received no financial support.

\section{References}

1. O JH, Lodge MA, Wahl RL. Practical PERCIST: A Simplified Guide to PET Response Criteria in Solid Tumors 1.0. Radiology 2016;280:576-584.

2. Li $X$, Rowe SP, Leal JP, Gorin MA, Allaf ME, Ross AE, Pienta KJ, Lodge MA, Pomper MG. Semiquantitative Parameters in PSMA-Targeted PET Imaging with 18F-DCFPyL: Variability in Normal-Organ Uptake. J Nucl Med 2017;58:942-946.

3. Sheikhbahaei S, Wray R, Young B, Mena E, Taghipour M, Rahmim A, Subramaniam RM. 18F-FDG-PET/CT therapy assessment of locally advanced pancreatic adenocarcinoma: impact on management and utilization of quantitative parameters for patient survival prediction. Nucl Med Commun 2016;37:231-238.

4. Keyes JW Jr. SUV: standard uptake or silly useless value? J Nucl Med 1995;36:1836-1839.

5. Lee JR, Madsen MT, Bushnel D, Menda Y. A threshold method to improve standardized uptake value reproducibility. Nucl Med Commun 2000;21:685-690

6. Ramos CD, Erdi YE, Gonen M, Riedel E, Yeung HW, Macapinlac HA, Chisin $\mathrm{R}$, Larson SM. FDG-PET standardized uptake values in normal anatomical structures using iterative reconstruction segmented attenuation correction and filtered back-projection. Eur J Nucl Med 2001;28:155164.

7. Sugawara $Y$, Zasadny KR, Neuhoff AW, Wahl RL. Reevaluation of the standardized uptake value for FDG: variations with body weight and methods for correction. Radiology 1999;213:521-525.

8. Perner S, Hofer MD, Kim R, Shah RB, Li H, Möller P, Hautmann RE, Gschwend JE, Kuefer R, Rubin MA. Prostate-specific membrane antigen expression as a predictor of prostate cancer progression. Hum Pathol 2007;38:696-701

9. Afshar-Oromieh A, Malcher A, Eder M, Eisenhut M, Linhart HG, Hadaschik BA, Holland-Letz T, Giesel FL, Kratochwil C, Haufe S, Haberkorn U, Zechmann CM. PET imaging with a [68Ga]gallium-labelled PSMA ligand for the diagnosis of prostate cancer: biodistribution in humans and first 
evaluation of tumour lesions. Eur J Nucl Med Mol Imaging 2013;40:486495.

10. Eiber $M$, Maurer $T$, Souvatzoglou $M$, Beer AJ, Ruffani A, Haller $B$, Graner FP, Kübler H, Haberkorn U, Eisenhut M, Wester HJ, Gschwend $\mathrm{JE}$, Schwaiger M. Evaluation of Hybrid ${ }^{68} \mathrm{Ga}$-PSMA Ligand PET/CT in 248 Patients with Biochemical Recurrence After Radical Prostatectomy. J Nucl Med 2015;56:668-674.

11. Rahbar K, Weckesser M, Huss S, Semjonow A, Breyholz HJ, Schrader AJ, Schäfers $M$, Bögemann $M$. Correlation of Intraprostatic Tumor Extent with ${ }^{68} \mathrm{Ga}$-PSMA Distribution in Patients with Prostate Cancer. J Nucl Med 2016;57:563-567.

12. Gafita A, Calais J, Franz C, Rauscher I, Wang H, Roberstson A, Czernin J, Weber WA, Eiber M. Evaluation of SUV normalized by lean body mass (SUL) in ${ }^{68} \mathrm{Ga}$-PSMA11 PET/CT: a bi-centric analysis. EJNMMI Res 2019;9:103.

13. D'Amico AV, Whittington $R$, Malkowicz SB, Schultz D, Blank $K$, Broderick GA, Tomaszewski JE, Renshaw AA, Kaplan I, Beard CJ, Wein A. Biochemical outcome after radical prostatectomy, external beam radiation therapy, or interstitial radiation therapy for clinically localized prostate cancer. JAMA 1998;280:969-974.

14. Rowe SP, Pienta KJ, Pomper MG, Gorin MA. PSMA-RADS Version 1.0: A Step Towards Standardizing the Interpretation and Reporting of PSMAtargeted PET Imaging Studies. Eur Urol 2018;73:485-487.

15. Janmahasatian S, Duffull SB, Ash S, Ward LC, Byrne NM, Green B. Quantification of lean bodyweight. Clin Pharmacokinet 2005;44:10511065.

16. Tahari AK, Chien D, Azadi JR, Wahl RL. Optimum lean body formulation for correction of standardized uptake value in PET imaging. J Nucl Med 2014;55:1481-1484.

17. Wahl RL, Jacene $H$, Kasamon $Y$, Lodge MA. From RECIST to PERCIST: Evolving Considerations for PET response criteria in solid tumors. J Nucl Med 2009;50 Suppl 1:122S-150S.
18. Uprimny C, Kroiss AS, Decristoforo C, Fritz J, von Guggenberg E, Kendler D, Scarpa L, di Santo G, Roig LG, Maffey-Steffan J, Horninger W, Virgolini IJ. ${ }^{68} \mathrm{Ga}-\mathrm{PSMA}-11 \mathrm{PET} / \mathrm{CT}$ in primary staging of prostate cancer: PSA and Gleason score predict the intensity of tracer accumulation in the primary tumour. Eur J Nucl Med Mol Imaging 2017;44:941-949.

19. Ergül N, Yilmaz Güneş B, Yücetaş U, Toktaş MG, Çermik TF. 68GaPSMA-11 PET/CT in Newly Diagnosed Prostate Adenocarcinoma. Clin Nucl Med 2018;43:e422-e427.

20. Liu C, Liu T, Zhang N, Liu Y, Li N, Du P, Yang Y, Liu M, Gong K, Yang X, Zhu $\mathrm{H}$, Yan K, Yang Z. ${ }^{68} \mathrm{Ga}-\mathrm{PSMA}-617$ PET/CT: a promising new technique for predicting risk stratification and metastatic risk of prostate cancer patients. Eur J Nucl Med Mol Imaging 2018;45:1852-1861.

21. Demirci $E$, Kabasakal L, Şahin $O E$, Akgün $E$, Gültekin $M H$, Doğanca $T$, Tuna MB, Öbek C, Kiliç M, Esen T, Kural AR. Can SUVmax values of Ga68-PSMA PET/CT scan predict the clinically significant prostate cancer? Nucl Med Commun 2019;40:86-91.

22. Pollard JH, Raman C, Zakharia Y, Tracy CR, Nepple KG, Ginader T, Breheny P, Sunderland JJ. Quantitative Test-Retest Measurement of ${ }^{68} \mathrm{Ga}-\mathrm{PSMA}$ HBED-CC in Tumor and Normal Tissue. J Nucl Med 2020;61:1145-1152.

23. Jansen BHE, Cysouw MCF, Vis AN, van Moorselaar RJA, Voortman J, Bodar YJL, Schober PR, Hendrikse NH, Hoekstra OS, Boellaard R, Oprea-Lager DE. Repeatability of Quantitative ${ }^{18} \mathrm{~F}-\mathrm{DCFPyL}$ PET/CT Measurements in Metastatic Prostate Cancer. J Nucl Med 2020;61:1320-1325.

24. Olde Heuvel J, de Wit-van der Veen BJ, Donswijk ML, Slump CH, Stokkel MPM. Day-to-day variability of [68Ga]Ga-PSMA-11 accumulation in primary prostate cancer: effects on tracer uptake and visual interpretation. EJNMMI Res 2020;10:132.

25. Onal C, Torun N, Akyol F, Guler OC, Hurmuz P, Yildirim BA, Cağlar M, Reyhan M, Ozyigit G. Integration of 68Ga-PSMA-PET/CT in Radiotherapy Planning for Prostate Cancer Patients. Clin Nucl Med 2019;44:e510-e516. 